\title{
Peers slam peer review
}

\section{London}

Systematic biology, the classification of living things based on evolutionary relationships, is a field in decline due to the failure of the peer-review process in Britain to recognize its "immeasurable" importance, according to a report last week from the Science and Technology Committee of the House of Lords.

Research proposals in systematics submitted to the public grant-making research councils also seem to fall between cracks. The few applications that are still made to the Science and Engineering Research Council (SERC) tended to lose to "more innovative research approaches", the report finds.

It also complains that the Advisory Board for the Research Councils (ABRC), which oversees the research councils, has not chosen to intervene to direct funds to neglected fields. Ironically, the plight of British systematics was noted in the ABRC's own report Taxonomy in Britain, published in 1979.

But times have changed, says Neil Chalmers, director of the Natural History Museum (NHM), noting the prominence of green politics and the forthcoming UNCED conference in June; administrators may now be more inclined to follow recommendations on systematics, he believes. Michael Claridge, president of the Systematics Association and one of the committee's two academic advisers, agrees. Because the government will be obliged to reply to the report in writing, he believes politicians will be forced to pay attention to systematics.

On money, the committee recommends that core funding should be maintained in real terms and that $\mathrm{ABRC}$ should set aside an extra $£ 1$ million a year for five years, partly to support courses designed to attract new blood. The committee argues that systematics should then "take its place with other branches of science". Lord Dainton, chairman of the committee, says the five-year programme would "make or break" the field.

Total British spending on systematics has remained at about $£ 30$ million a year since 1980 , and so has been a declining proportion of the total science budget, which has increased by 28 per cent in real terms since then. The committee also notes that 'core' funding for systematics research fell from $£ 11.5$ million in 1980 to $£ 10.4$ million in 1990 , and that research council support fell by more than a third during the same period, from $£ 3.3$ million to $£ 2.0$ million.

Research manpower in museums also fell, between 1980 and 1990, by 25 per cent - even before the substantial job cuts at the NHM announced in 1990 which provoked the House of Lords inquiry.
There has also been a shift towards shortterm contract employment; 99 per cent of museum systematists were permanently employed in 1980, compared with 66 per cent in 1990.

The proportion of time spent studying systematics by biology undergraduates has more than halved since 1980 , from 17.1 to 8.9 per cent, in line with and perhaps because of the increased popularity of modular courses at British universities.

The changing age structure of university systematists is also, as Chalmers puts it, "very worrying": in 1980, 24 per cent of systematics teachers in universities were under 35 and 44 per cent were 46 or more. Just ten years later, only 8 per cent were under 35 and 63 per cent had passed 46 . Plainly, experts are retiring or dying off and are not being replaced.

Museums employ the lion's share of systematists and thus consume most core funding. The NHM is now supported through the Office of Arts and Libraries (OAL), which has been much criticized for not appreciating the scientific work at NHM. Chalmers says he will continue to press for "level funding". The Lords committee also recommends that OAL should be advised by a science panel and that there should be a rolling fund of $£ 0.5$ million a year to support the curation of natural history collections at institutions such as local museums.

Curation is a strong theme in the House of Lords report. Many witnesses emphasized that the best-kept collections are those in which researchers take an active interest. This sentiment was prompted by moves at NHM to separate curation and research as distinct jobs. The report sidesteps this issue, but recommends that no collection should be without the attention of an active researcher, even if part-time or peripatetic.

The committee also urges that bodies concerned with systematics should set up a forum to keep the situation under review, and to rationalize the present dispersed and disorganized roster of British collections. What the committee has in mind is an extension of the 1961 agreement dividing research and curation of specimens of the world's flora between NHM and the Royal Botanic Gardens at Kew. John Marsden, executive secretary of the Linnean Society of London, agrees with Claridge that "it's the only way to solve the enormous problem of documenting biological diversity".

Dainton (a chemist) says he is now firmly convinced of the potential benefits of systematic biology, attainable with modest increases in expenditure. "The cost of getting it right is small" he says: "the cost of getting it wrong is enormous."

Henry Gee
Jones's head rolls

\section{London}

DAVID Jones, the much-criticized general director of London Zoo, has emerged as the major casualty of the zoo's financial crisis. The Council of the Zoological Society of London, which runs the zoo, has decided to abolish Jones's post from $\mathbf{3 0}$ April. The zoo's two sites, the troubled Regent's Park site in central London, and Whipsnade Zoo, north of the capital, will in future be run by separate directors. $A$ new management committee of society council members is expected to take a stronger role in defining the zoo's strategy.

Zoological Society fellows who last month inflicted a damaging vote of no confidence in their council's past performance, but stopped short of demanding the council's resignation after receiving assurances that the zoo's management would be overhauled (see Nature 355, 100; 9 January 1992), now claim an important victory, and believe the threat of closure for the Regent's Park site is receding.

Colin Tudge, a zoologist and writer and one of the leaders of the so-called 'Reform Group' of society fellows that proposed the no confidence motion, believes that Jones's departure is necessary to restore the zoo management's credibility. Jones, he says, was too closely associated with a series of expensive investment plans, mooted since the mid-1980s, that failed to secure the zoo's long-term financial future and eventually led to the threat of closure for the Regent's Park site.

Jones was also damaged by the unfavourable public reaction to the disclosure of the zoo's financial plight. At the time, it was suggested that zoo animals might have to be destroyed, if the UK government did not provide money to save the zoo. When it emerged that this slaughter was unlikely to happen, many supporters of the zoo expressed distaste at the zoo management's tactics.

Nevertheless, the society's council is considering setting up a new position of overseas director to allow Jones to remain affiliated with the zoo. Tudge is pleased that the council seems to have largely abandoned the expensive plans to relaunch the Regent's Park site around a series of 'themed' exhibits, which have been priced at between $£ 12$ million and $£ 60$ million. He says that the council's latest plans have borrowed heavily from the low- budget proposals put forward by the Reform Group, which place emphasis on the zoo's captive breeding programmes. Tudge believes the council's latest estimate to redevelop the site, of $£ 9$ million, may be reduced still further, increasing the likelihood that sponsors will come forward. A possible closure of the Regent's Park Zoo in the autumn "no longer seems to be on the agenda," he says. Peter Aldhous 